\title{
Influence of the Composition of Solid Fuel on the Equilibrium Characteristics of a Gasification Process in the Mixtures of Oxygen and Carbon Dioxide
}

\author{
I. G. Donskoi ${ }^{a, *}$ \\ ${ }^{a}$ Melentiev Energy Systems Institute, Siberian Branch, Russian Academy of Sciences, \\ Irkutsk, 664033 Russia \\ *e-mail:donskoy.chem@mail.ru \\ Received February 5, 2021; revised March 17, 2021; accepted April 6, 2021
}

\begin{abstract}
The gasification of solid fuels of different elemental compositions in $\mathrm{O}_{2} / \mathrm{N}_{2}$ and $\mathrm{O}_{2} / \mathrm{CO}_{2}$ mixtures was studied using equilibrium thermodynamic modeling. The dependences of process characteristics (temperature and the yield of carbon residue) on the composition of gasification agent and the stoichiometric ratio were calculated. The addition of carbon dioxide, on the one hand, promoted the conversion of carbon due to an increase in the concentration of gasifying agents and, on the other hand, decreased the process temperature due to an increase in heat capacity and an endothermic effect of the gasification reaction. The efficiency of using $\mathrm{O}_{2} / \mathrm{CO}_{2}$ mixtures for the gasification of fuels increased with the carbon content. The highest chemical efficiency of coke and coal gasification was achieved at an initial $\mathrm{CO}_{2}$ concentration of about $40-60 \mathrm{vol} \%$.
\end{abstract}

Keywords: gasification, carbon dioxide, coal, biomass, thermodynamic modeling

DOI: $10.3103 / \mathrm{S} 0361521921040029$

An improvement in the environmental efficiency of the use of solid fuel requires the development of new technologies for its thermochemical conversion. One of the main problems in the use of solid fuels is the inevitable formation of significant amounts of carbon dioxide [1]. The emissions of $\mathrm{CO}_{2}$ can be reduced with the use of new carbon capture and storage (CCS) technologies, such as integrated gasification combined cycle (IGCC) power plants, and oxyfuel combustion processes $[2,3]$. In this case, $\mathrm{CO}_{2}$ can be extracted in two possible ways. The first is the removal of carbon before the combustion chamber (pre-combustion), when the producer gas is converted with water vapor, which makes it possible to use $\mathrm{CO}$ to obtain additional $\mathrm{H}_{2}$, and the conversion products are separated (by absorption, membrane, and chemical methods) [4, 5]. Thereafter, the gas enriched in hydrogen is burned, and $\mathrm{CO}_{2}$ is concentrated and sent for disposal. The second method is the removal of carbon from combustion products (post-combustion), which is similar to that for traditional CCS systems: the gas mixture is cooled and compressed to condensation conditions; thereafter, $\mathrm{CO}_{2}$ is separated from other gases and disposed. It is possible to simplify the removal of $\mathrm{CO}_{2}$ in the post-combustion version with the help of oxyfuel combustion, when the oxygen concentration in the blast is usually higher than that in air, and a mixture of combustion products $-\mathrm{CO}_{2}$ and $\mathrm{H}_{2} \mathrm{O}$ - plays the role of ballast instead of nitrogen. Combustion in a mixture of oxygen and combustion products has better environmental characteristics compared to those of traditional combustion in air: first, it is obvious that less nitrogen oxides (only fuel ones) are formed; second, the resulting flue gases can be purified to high concentrations of $\mathrm{CO}_{2}$, allowing its easy utilization. Combustion technologies in mixtures with combustion products are considered the most technically efficient; however, at the same time, they are among the most expensive versions of CCS systems [6, 7]. Among other problems, in addition to the high cost, it is possible to note the requirements for the purification of flue gases from sulfur and nitrogen oxides [8]. Combined technologies, for example, the combustion of fuels with dilution with hot combustion products [9] and the use of $\mathrm{CO}_{2}$ as a blowing agent in pulverized coal gasification $[10,11]$ have been studied.

The combustion of producer gas with the recirculation of $\mathrm{CO}_{2}$ from combustion products was considered $[12,13]$. It was found $[14,15]$ that an excess of $\mathrm{CO}_{2}$ in the composition of a working fluid decreased the efficiency of a gas turbine plant. The use of $\mathrm{CO}_{2}$ as a working fluid in combined cycles was also proposed [16, 17].

The use of $\mathrm{CO}_{2}$ as a transport medium for coal particles in the oxygen gasification of coal increased the average degree of fuel conversion [18, 19], but the flame stability region narrowed in this case [20]. In an 
Table 1. Composition of fuels

\begin{tabular}{|c|c|c|c|c|c|}
\hline Fuel characteristic & Designation & Coke & Coal & Brown coal & Biomass \\
\hline Moisture content on an as-received basis & $W^{r}, \%$ & 5 & 9 & 12 & 10 \\
\hline Ash content on a dry matter basis & $A^{d}, \%$ & 10 & 20 & 9 & 1 \\
\hline Yield of volatiles on a dry ash-free basis & $V^{d a f}, \%$ & 9 & 30 & 48 & 85 \\
\hline Carbon content on a dry ash-free basis & $\mathrm{C}^{d a f}, \%$ & 92 & 81 & 69.4 & 49.5 \\
\hline Hydrogen content on a dry ash-free basis & $\mathrm{H}^{d a f}, \%$ & 2.5 & 3.5 & 4.9 & 6.3 \\
\hline Oxygen content on a dry ash-free basis & $\mathrm{O}^{d a f}, \%$ & 4.99 & 13.2 & 24.3 & 44.15 \\
\hline Nitrogen content on a dry ash-free basis & $\mathrm{N}^{d a f}, \%$ & 0.01 & 2.0 & 0.9 & 0.05 \\
\hline Sulfur content on a dry ash-free basis & $\mathrm{S}^{d a f}, \%$ & 0.5 & 0.3 & 0.5 & 0 \\
\hline
\end{tabular}

atmosphere of carbon dioxide, oxygen diffusion to the combustion region slowed down, and the concentration of active particles decreased. The intensity of heat release at the combustion front can decrease by $20-$ $25 \%$ [21]. As a rule, widely used diffusion-kinetic models with different corrections for the structure of a surface layer are used to describe the burnup of single particles; however, at a high concentration of carbon dioxide, the contribution of individual reactions can change significantly $[22,23]$. A change in the composition of a gas atmosphere leads to changes in heat and mass transfer conditions, which also affect the behavior of fuel particles [24, 25]. Maffei et al. [26] considered a problem of the ignition of a coal particle with a more detailed analysis of the chemical kinetics of decomposition of the organic matter in one-dimensional version. Ralnikov et al. [27] studied the effect of oxygen concentration on the temperature profile in a reactor.

Equilibrium thermodynamic models and their combinations with the models of heterogeneous kinetics are often used to simplify the submodels of thermochemical transformations [28, 29]. Earlier [30], a version of kinetic-thermodynamic models was applied to study the efficiency of the high-temperature gasification of coal dust in $\mathrm{O}_{2} / \mathrm{CO}_{2}$ mixtures: according to calculations, a high concentration of $\mathrm{CO}_{2}$ allows more efficient use of the heat of combustion of fuel even with a decrease in the reaction temperature (due to the high heat capacity of $\mathrm{CO}_{2}$ ). In this work, the process of gasification without blast heating is considered.

\section{THERMOCHEMICAL EQUILIBRIUM MODEL AND INITIAL DATA}

Thermodynamic modeling was carried out to study the boundaries of the thermochemical efficiency of the carbon dioxide conversion of solid fuels. Svishchev and Keiko [31] applied a similar model to assess the effect of excess water vapor on the process efficiency of coal gasification.
In the gasification of solid fuel, the following overall reactions are of decisive importance:

$$
\begin{gathered}
\mathrm{CH}_{a} \mathrm{O}_{b} \mathrm{~N}_{c} \mathrm{~S}_{d}=b_{1} \mathrm{C}+b_{2} \mathrm{H}_{2}+b_{3} \mathrm{~N}_{2} \\
+b_{4} \mathrm{H}_{2} \mathrm{~S}+b_{5} \mathrm{NH}_{3}+b_{6} \mathrm{CO}+b_{7} \mathrm{CO}_{2}+b_{8} \mathrm{H}_{2} \mathrm{O} \\
2 \mathrm{C}+\mathrm{O}_{2}=2 \mathrm{CO} \\
\mathrm{C}+\mathrm{CO}_{2}=2 \mathrm{CO} \\
\mathrm{C}+\mathrm{H}_{2} \mathrm{O}=\mathrm{CO}+\mathrm{H}_{2} \\
2 \mathrm{CO}+\mathrm{O}_{2}=\mathrm{CO}_{2} \\
2 \mathrm{H}_{2}+\mathrm{O}_{2}=2 \mathrm{H}_{2} \mathrm{O} \\
\mathrm{CO}+\mathrm{H}_{2} \mathrm{O}=\mathrm{CO}_{2}+\mathrm{H}_{2}
\end{gathered}
$$

Reaction (1) simulates the process of pyrolysis: the composition of the products and the heat effect of this reaction are ambiguously determined by the initial composition, and they depend on the reaction conditions (including dynamic characteristics; however, these parameters are not taken into account in equilibrium modeling). The sum of reactions (2), (3), and (5) results in the complete combustion of carbon to carbon dioxide. At a high concentration of carbon dioxide in the initial state, the equilibrium in reaction (3) shifts toward the products; on the contrary, the equilibrium in reactions (5) and (7) shifts toward the reactants. Therefore, an increase in the degree of fuel conversion and a decrease in the yield of hydrogen can be expected under gasification conditions with the dilution of oxygen with carbon dioxide.

For the gas phase, the equation of state of an ideal gas is adopted, and condensed substances form ideal one-component phases. Then, the problem of calculating the chemical state of the gas phase takes the following form [32]:

Find $\mathbf{n}^{e q}=\arg \max S(\mathbf{n})$ under the conditions

$$
\begin{gathered}
S(\mathbf{n}, T)=\sum_{j=1}^{N_{g}} n_{j}^{g}\left(s_{j}^{g}(T)+R \ln \frac{n_{j}^{g}}{\sigma^{g}}\right)+\sum_{k=1}^{N_{c}} n_{j}^{c} s_{j}^{c}(T), \\
\mathbf{A}\left(\mathbf{n}-\mathbf{n}^{\mathrm{in}}\right)=0,
\end{gathered}
$$


(a)

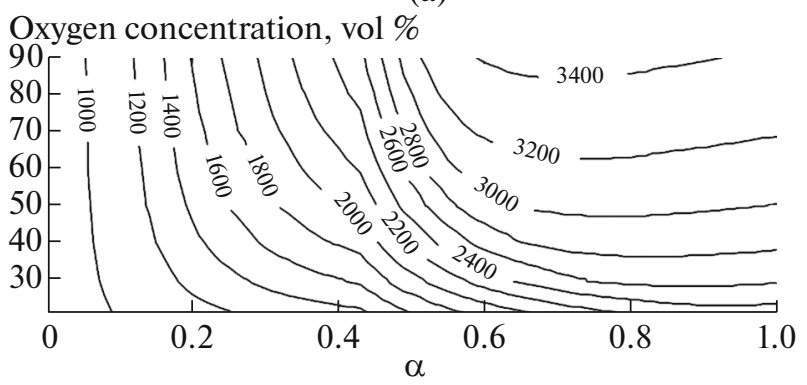

(b)

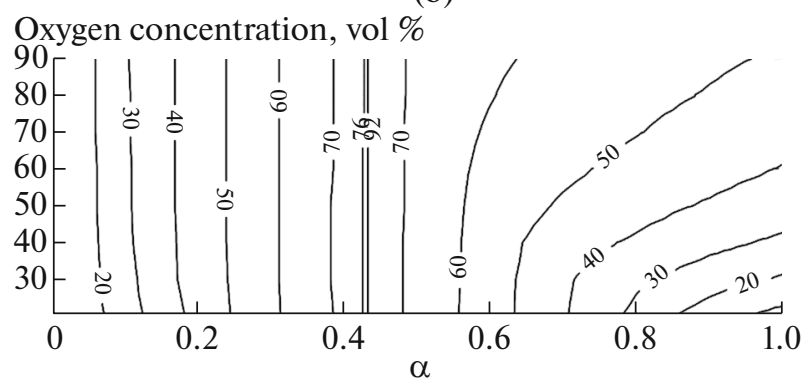

(c)

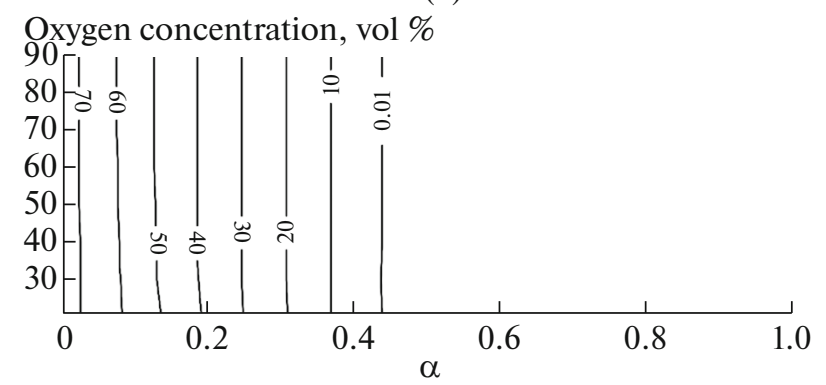

(d)

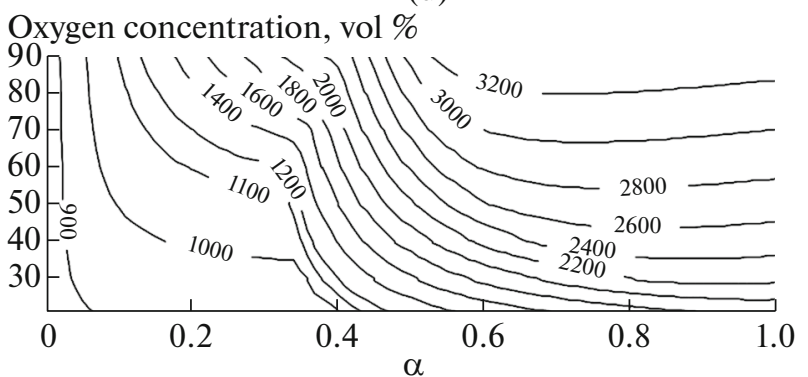

(e)

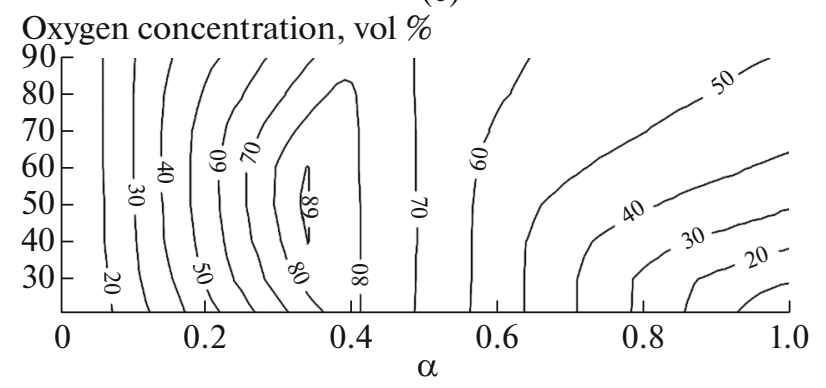

(f)

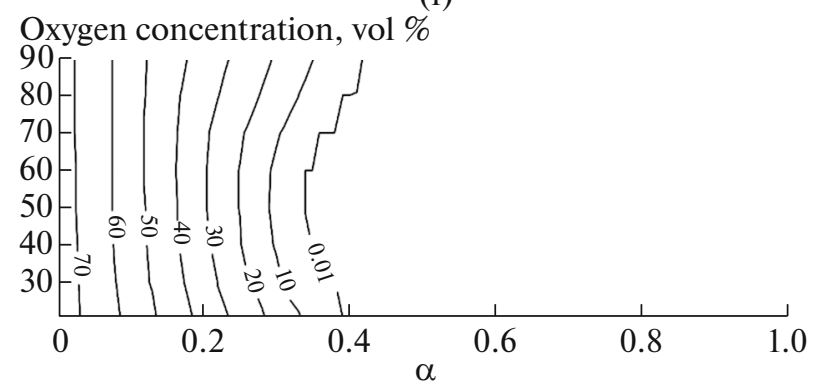

Fig. 1. Calculated process characteristics of coke gasification in the mixtures of $(a-c) \mathrm{O}_{2} / \mathrm{N}_{2}$ and $(\mathrm{d}-\mathrm{f}) \mathrm{O}_{2} / \mathrm{CO}_{2}:(\mathrm{a}$, d) adiabatic temperature, $\mathrm{K} ;(\mathrm{b}, \mathrm{e})$ cold gas efficiency, \%; and (c, f) yield of carbon, $\mathrm{mol} / \mathrm{kg}$.

$$
\begin{aligned}
\sum_{j}^{N_{\mathrm{g}}+N_{c}} h_{j}(T) n_{j} & =\sum_{j}^{N_{g}+N_{c}} h_{j}\left(T^{\mathrm{in}}\right) n_{j}^{\mathrm{in}}, \\
\mathbf{n} & \geq 0 .
\end{aligned}
$$

Here, $S$ is the thermochemical entropy of the system, $\mathrm{J} / \mathrm{K} ; \mathbf{n}$ is the vector of the composition of the system, $\mathrm{mol}\left(\mathbf{n}^{\text {in }}\right.$ is the vector of the initial composition, and $\mathbf{n}^{\text {eq }}$ is the equilibrium composition); the superscripts $g$ and $\mathrm{c}$ refer to the gas phase and condensed phases, respectively; $s_{j}$ is the specific molar entropy of the $j$ th component, $\mathrm{J} \mathrm{mol}^{-1} \mathrm{~K}^{-1} ; h_{j}$ is the specific molar enthalpy of the $j$ th component, $\mathrm{J} / \mathrm{mol} ; R$ is the universal gas constant; $\sigma^{\mathrm{g}}$ is the total number of moles of the gas phase, mol; and $\mathbf{A}$ is the material balance matrix (matrix of the elemental composition of components). The thermochemical data of substances were taken from [33]. The enthalpy of solid fuels is determined through the calorific value and the enthalpies of combustion products. Because gasification regimes were of primary interest, the initial fuel was absent in an equilibrium state and underburning were modeled by pure carbon.
In this regard, the solution was insensitive to the specific entropies of the initial fuel: their values can be taken with a large degree of arbitrariness.

The solution to the equilibrium problem in the adopted approximations exists, and it is unique, as follows from the convexity of entropy for these systems $[34,35]$. A version of the optimal descent method was used for numerical solution [34].

The indicators of the efficiency of regimes are the adiabatic process temperature, the yield of solid residue, and the cold gas efficiency of gasification, which is a ratio between the heats of combustion of producer gas and the fuel from which it was obtained:

$$
\eta=\frac{q_{\mathrm{CO}} n_{\mathrm{CO}}+q_{\mathrm{H}_{2}} n_{\mathrm{H}_{2}}+q_{\mathrm{CH}_{4}} n_{\mathrm{CH}_{4}}}{Q_{f}} \times 100 \%
$$

Here, $Q_{f}$ is the specific calorific value of the fuel, $q_{j}$ is the calorific value of the $j$ th gaseous product, and $n_{j}$ is the equilibrium yield of the $j$ th gaseous product per $1 \mathrm{~kg}$ of the initial fuel. The calorific value of gas is cal- 
(a)

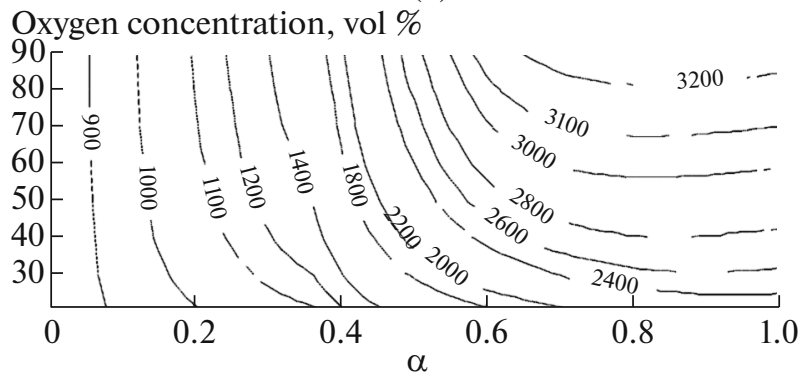

(b)

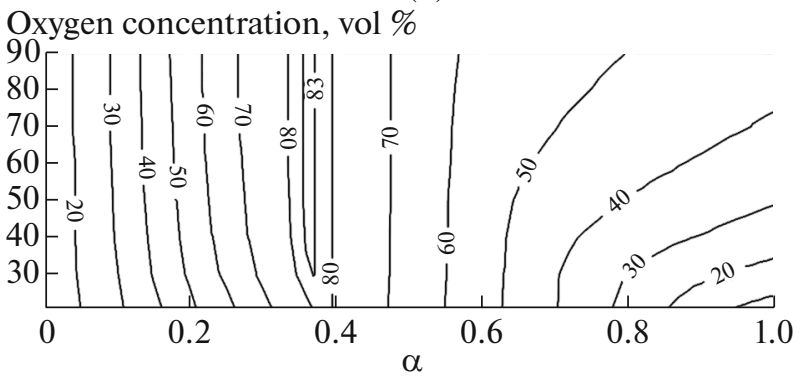

(c)

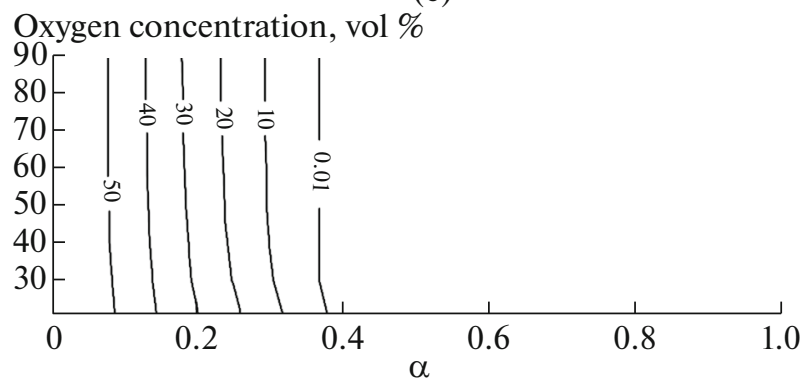

(d)

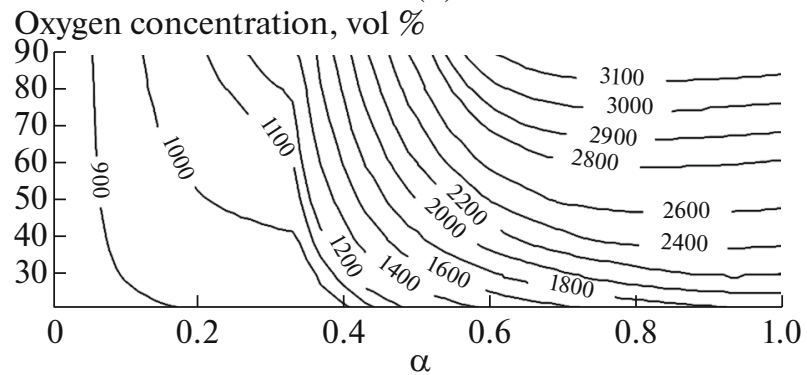

(e)

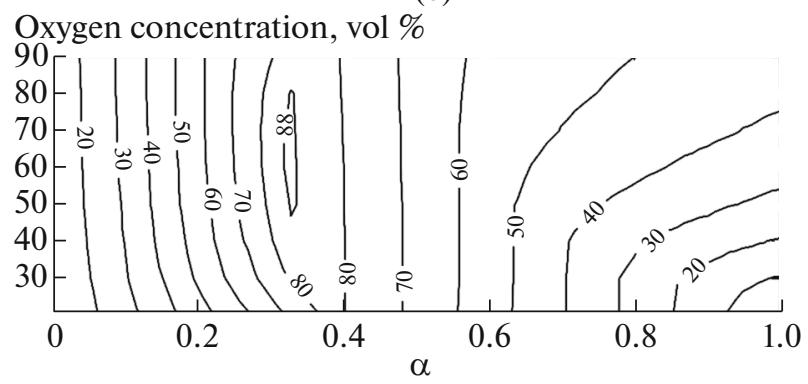

(f)

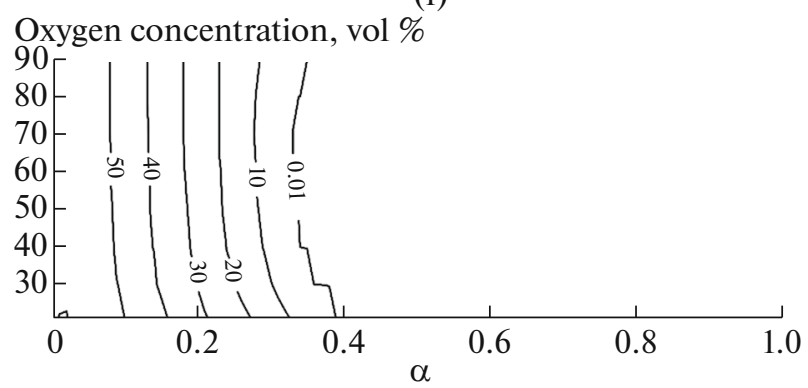

Fig. 2. Calculated process characteristics of coal gasification in the mixtures of $(a-c) \mathrm{O}_{2} / \mathrm{N}_{2}$ and $(\mathrm{d}-\mathrm{f}) \mathrm{O}_{2} / \mathrm{CO}_{2}$ : (a, d) adiabatic temperature, $\mathrm{K}$; (b, e) cold gas efficiency, \%; and (c, f) yield of carbon, mol $/ \mathrm{kg}$.

culated based on the main combustible components: $\mathrm{CO}, \mathrm{H}_{2}$, and $\mathrm{CH}_{4}$. The equilibrium cold gas efficiency of gasification is determined by stoichiometric and temperature factors [36]. In this work, only the influence of the fuel composition and the fuel/oxidizer ratio was investigated. The initial temperature of a gasifying agent in all cases was $300 \mathrm{~K}$, and the pressure was $1 \mathrm{~atm}$. Calculations were carried out using the resources of the High-Temperature Curcuit MultiAccess Research Center (Ministry of Science and Higher Education of the Russian Federation, project no. 13.CKP.21.0038).

To assess the influence of the fuel grade, calculations were carried out for four fuels with different compositions. Coke and biomass are example of an ideal fuel with high carbon content and a low-calorie fuel, respectively. Kuznetsk hard coal and brown coal from the Berezovo deposit [37] were taken for the calculations. Table 1 summarizes the composition of the fuels.
In addition to the fuel composition, variable parameters in the calculations were the relative oxidizer consumption $\alpha$ (calculated in relation to the stoichiometric consumption of oxygen) and the oxygen concentration in gasification agent (from 21 to $90 \mathrm{vol} \%$ ); the diluents were nitrogen (traditional modes) and carbon dioxide (promising modes).

\section{RESULTS AND DISCUSSION}

The equilibrium process characteristics of coke gasification (Fig. 1) in $\mathrm{O}_{2} / \mathrm{N}_{2}$ mixtures weakly depended on the concentration of oxygen: the isolines of chemical efficiency were parallel to the abscissa axis to the values of $\alpha$ of about 0.5. At high temperatures, the course of isolines changed due to the thermal dissociation of combustion products (the displacement of isolines was observed with all fuels). Note that thermochemical data for temperatures higher than $3000 \mathrm{~K}$ were determined by the extrapolation of published data [33]; 
(a)

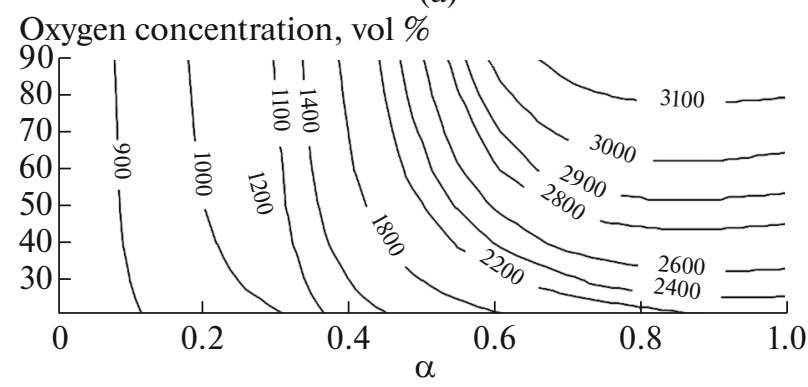

(b)
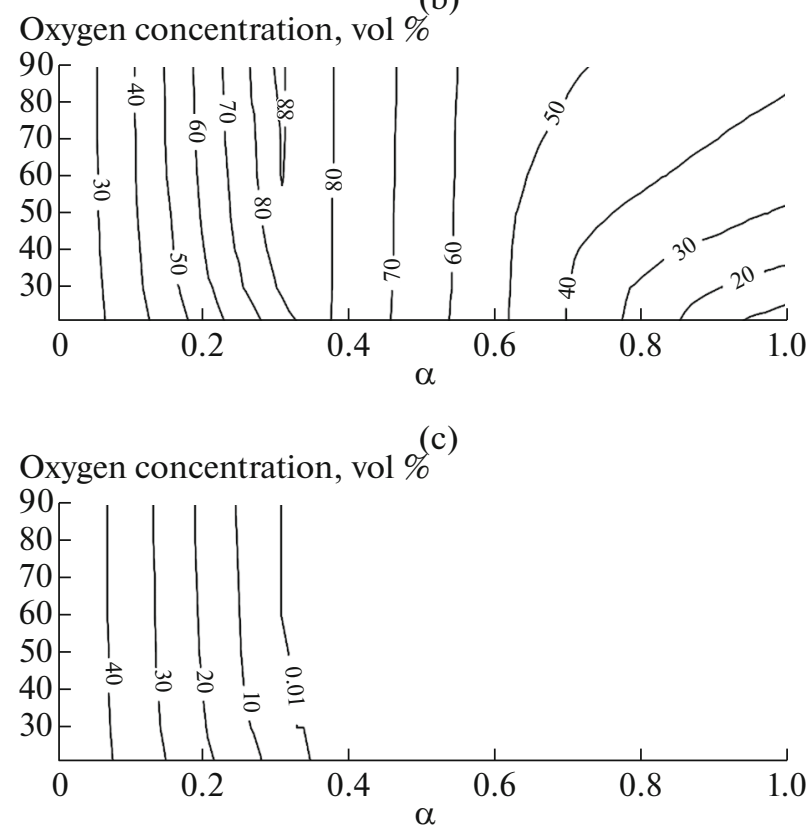

(d)

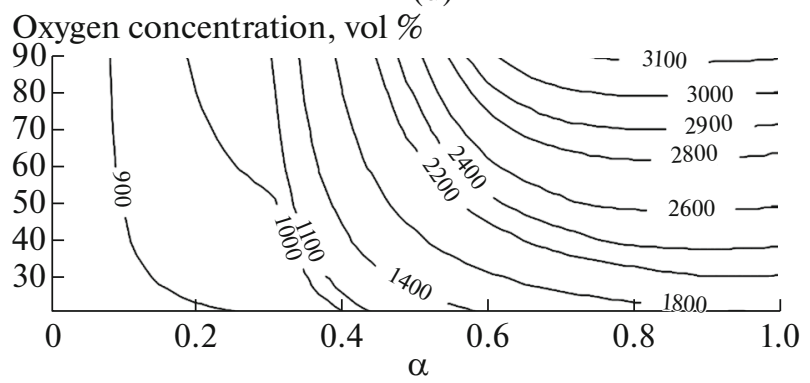

(e)
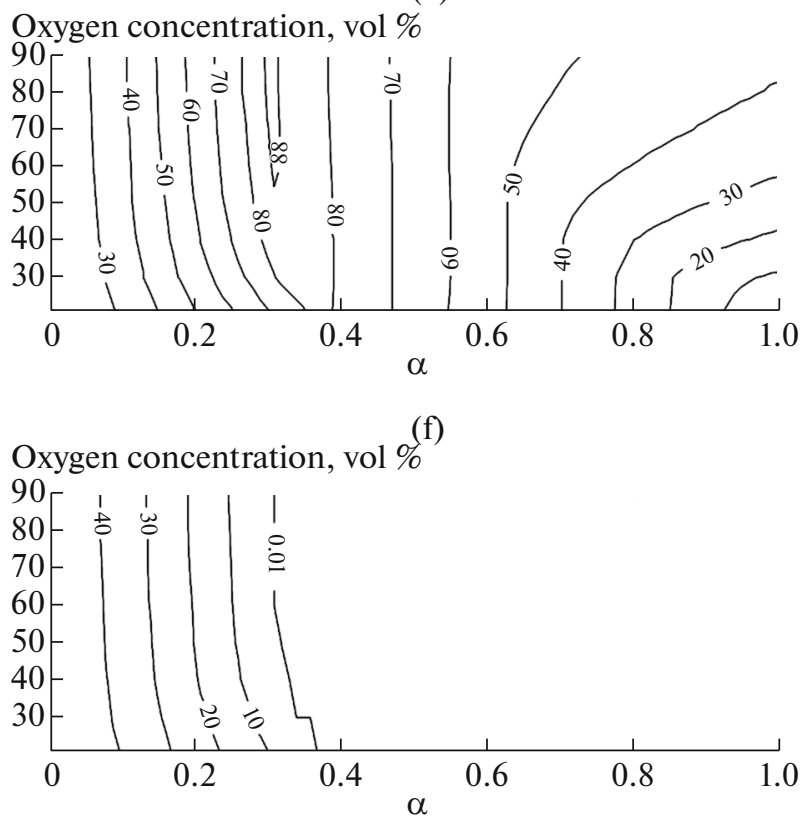

Fig. 3. Calculated process characteristics of brown coal gasification in the mixtures of $(a-c) \mathrm{O}_{2} / \mathrm{N}_{2}$ and $(d-f) \mathrm{O}_{2} / \mathrm{CO}_{2}$ : (a, d) adiabatic temperature, $\mathrm{K}$; (b, e) cold gas efficiency, \%; and (c, f) yield of carbon, $\mathrm{mol} / \mathrm{kg}$.

however, this range of parameters was almost out of reach due to the requirements for materials. A maximum chemical efficiency in $\mathrm{O}_{2} / \mathrm{N}_{2}$ mixtures was $72 \%$, and it was almost independent of the concentration of oxygen. In $\mathrm{O}_{2} / \mathrm{CO}_{2}$ mixtures, the maximum chemical efficiency sharply increased to $89 \%$ because of the beneficial use of heat in endothermic gasification reactions due to $\mathrm{CO}_{2}$, which was present in excess in the gas phase. The region of complete conversion also shifted to lower oxidant consumption.

The adiabatic temperature of coke gasification under conditions of oxygen dilution with combustion products was much lower because the specific molar heat capacity of $\mathrm{CO}_{2}$ is higher than that of $\mathrm{N}_{2}$ and the gasification reaction has an endothermic effect. As the oxygen concentration increased, the effect of a diluent decreased; therefore, the behaviors of characteristics in the upper part of diagrams almost coincided.

Similar patterns were observed in the gasification of coal (Fig. 2); however, the maximum chemical effi- ciency in $\mathrm{O}_{2} / \mathrm{N}_{2}$ mixtures was about $83 \%$ due to a lower carbon content of the composition. The gasification temperature was lower due to a lower calorific value, as compared to that of coke. In gasification in $\mathrm{O}_{2} / \mathrm{CO}_{2}$ mixtures, the maximum cold gas efficiency was $88 \%$, that is, almost at the same level as in the case of coke.

For brown coal (Fig. 3), the maximum efficiency values in $\mathrm{O}_{2} / \mathrm{N}_{2}$ and $\mathrm{O}_{2} / \mathrm{CO}_{2}$ mixtures were similar: about $88 \%$ for both of the diluents. The topology of cold gas efficiency for both types of the mixtures was almost the same (in particular, the maximum values were achieved with the same parameters), although the difference in temperatures in the same range of parameters $(\alpha=0.4-0.6)$, on the contrary, was the largest. Brown coal as a fuel with a high yield of volatiles can be gasified at lower values of $\alpha$, as compared with hard coal in $\mathrm{O}_{2} / \mathrm{N}_{2}$ mixtures. However, due to its lower calorific value, the reaction temperature is insufficient for the efficient utilization of heat in the 
(a)

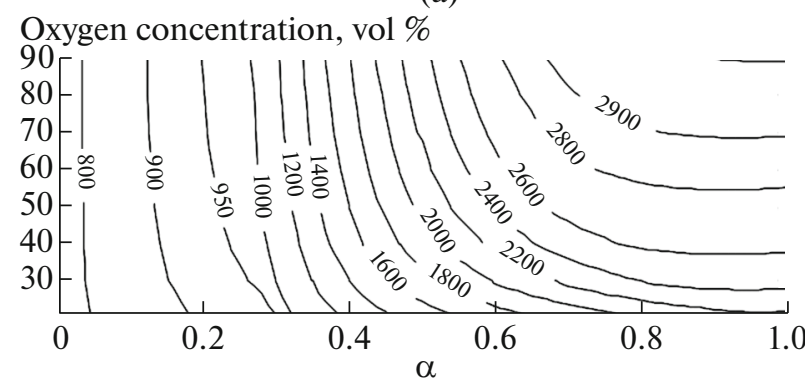

(b)

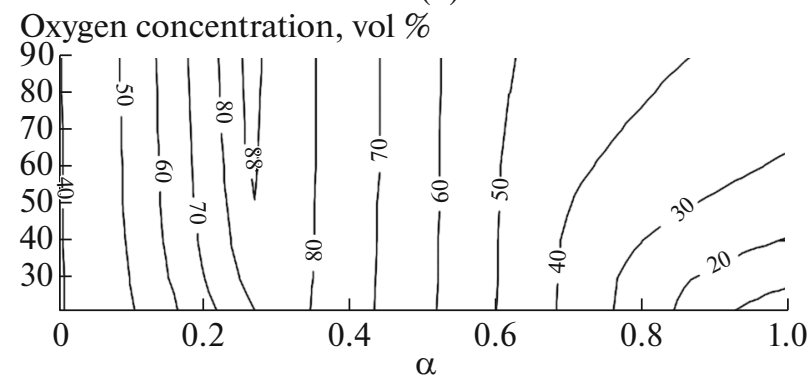

(c)

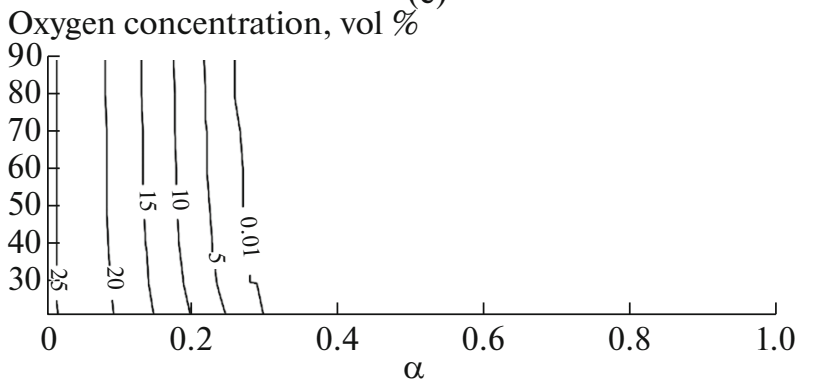

(d)

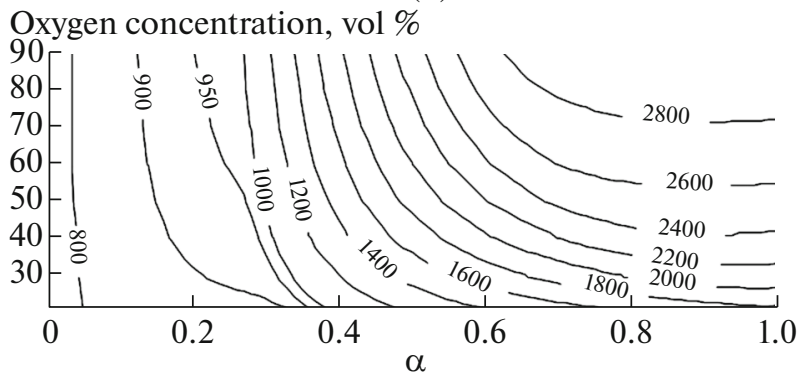

(e)

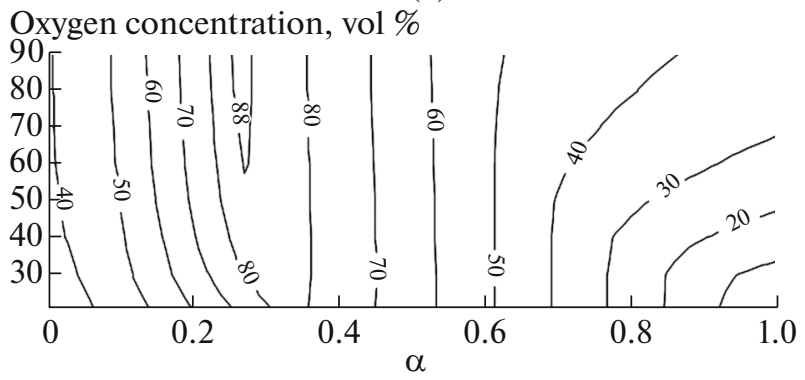

(f)

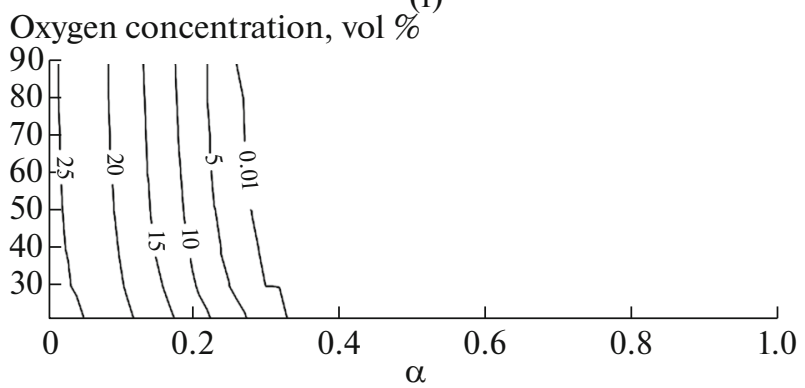

Fig. 4. Calculated process characteristics of biomass gasification in the mixtures of $(a-c) \mathrm{O}_{2} / \mathrm{N}_{2}$ and $(\mathrm{d}-\mathrm{f}) \mathrm{O}_{2} / \mathrm{CO}_{2}$ : (a, d) adiabatic temperature, $\mathrm{K} ;(\mathrm{b}, \mathrm{e})$ cold gas efficiency, \%; and (c, f) yield of carbon, $\mathrm{mol} / \mathrm{kg}$.

reaction of fuel carbon with carbon dioxide; therefore, the gasification of brown coal in $\mathrm{O}_{2} / \mathrm{CO}_{2}$ mixtures requires slightly larger values of $\alpha$, and the formation of combustible components due to the addition of $\mathrm{CO}_{2}$ is leveled by the addition of an oxidizing agent.

In the gasification of biomass (Fig. 4), the same regularities were observed as those for brown coal. Biomass is fuel with the highest yield of volatile substances (among those considered in this work); therefore, a change in the composition of a mixture from $\mathrm{O}_{2} / \mathrm{N}_{2}$ to $\mathrm{O}_{2} / \mathrm{CO}_{2}$ led to a deterioration in the characteristics of gas at low oxygen concentrations, and it did almost not change them at high oxygen concentrations.

Figure 5 shows the maximum values of equilibrium cold gas efficiency for different oxidant concentrations. Differences between the dependences of the chemical efficiency in $\mathrm{O}_{2} / \mathrm{N}_{2}$ and $\mathrm{O}_{2} / \mathrm{CO}_{2}$ became less and less noticeable (although they did not disappear) with an increase in the yield of volatiles and a decrease in the weight concentration of carbon in the fuel. The higher the carbon content of fuel, the greater the positive effect of the use of $\mathrm{CO}_{2}$ as a diluent: the oxidation of the volatile substances of brown coal and biomass produced a sufficient amount of gaseous oxidants for the regeneration of heat released on oxidation. Thus, high-carbon fuels such as coal and coke are the most suitable fuels for gasification in $\mathrm{O}_{2} / \mathrm{CO}_{2}$ mixtures.

\section{CONCLUSIONS}

The limiting processes efficiency of the gasification of different types of solid fuel in $\mathrm{O}_{2} / \mathrm{CO}_{2}$ mixtures was studied with the use of equilibrium thermodynamic modeling. In contrast to gasification processes in $\mathrm{O}_{2} / \mathrm{N}_{2}$ mixtures, stoichiometric restrictions on the conversion of carbon were weakened with the use of $\mathrm{O}_{2} / \mathrm{CO}_{2}$ mixtures. The $\mathrm{CO}_{2}$ present in excess reacted with carbon to increase the yield of combustible gases, but it significantly lowered the temperature (by 100- 

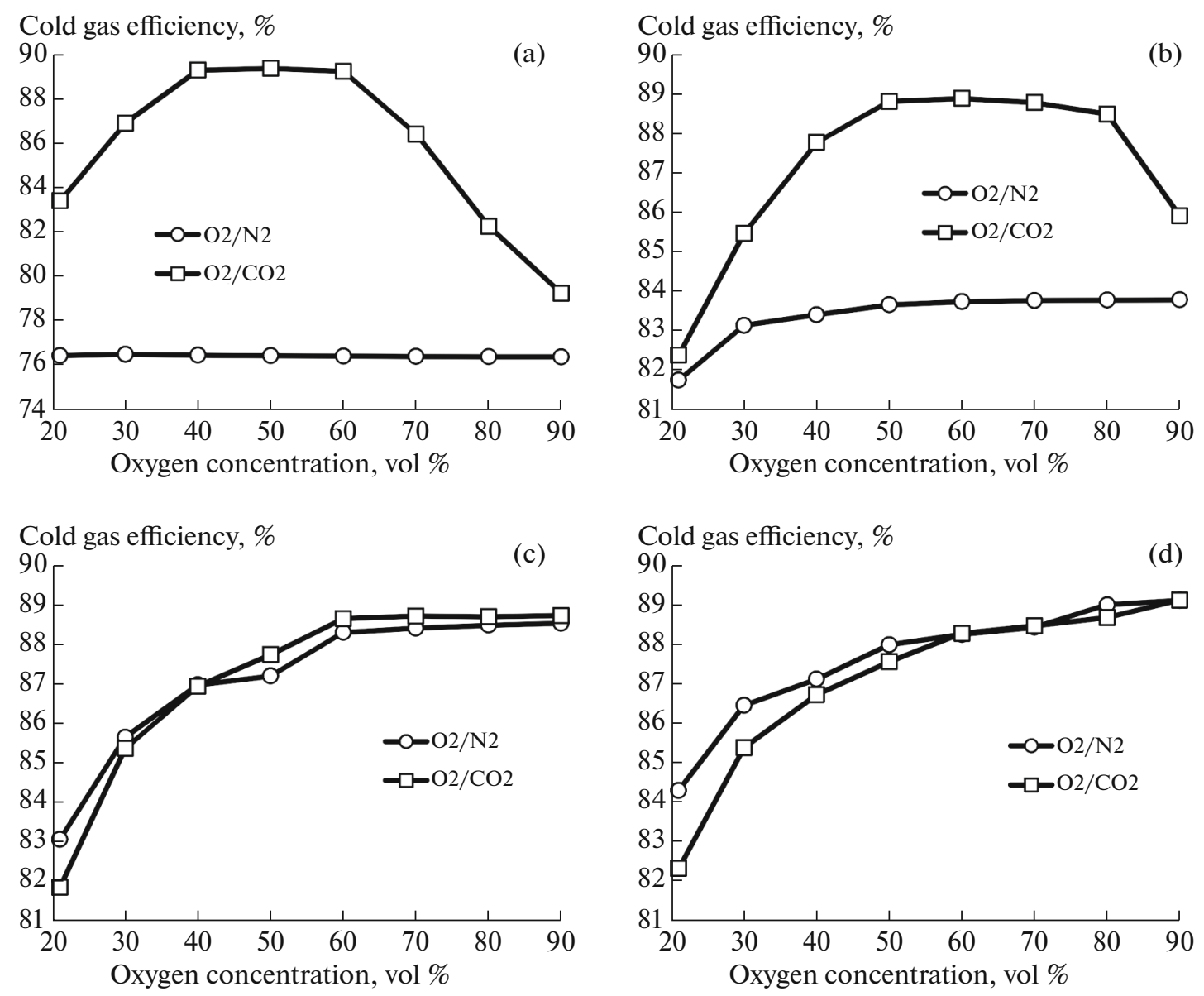

Fig. 5. Comparison between the maximum cold gas efficiencies of gasification of different fuels in $\mathrm{O}_{2} / \mathrm{N}_{2}$ and $\mathrm{O}_{2} / \mathrm{CO}_{2}$ mixtures: (a) coke, (b) coal, (c) brown coal, and (d) biomass.

$200 \mathrm{~K})$. The effect of the use of $\mathrm{CO}_{2}$ also depended on the concentration of oxygen: at low oxygen concentrations, the process temperature was insufficiently high due to dilution (in this case, the use of $\mathrm{CO}_{2}$, on the contrary, decreased the cold gas efficiency of gasification of brown coal and biomass); at high oxygen concentrations, the concentration of $\mathrm{CO}_{2}$ was insufficiently high for the effective conversion of carbon. Under these conditions, the use of $\mathrm{O}_{2} / \mathrm{CO}_{2}$ mixtures as a gasifying agent was beneficial only for high-carbon fuels. The greatest effect was observed at an oxygen concentration of 50-60 vol \%. Carbon dioxide can also act as an additive to control the process temperature, for example, with the use of a combination blast.

\section{FUNDING}

This work was carried out within the framework of a grant of the President of the Russian Federation for state support of young candidates of sciences (MK-157.2020.8).

\section{OPEN ACCESS}

This article is licensed under a Creative Commons Attribution 4.0 International License, which permits use, sharing, adaptation, distribution and reproduction in any medium or format, as long as you give appropriate credit to the original author(s) and the source, provide a link to the Creative Commons license, and indicate if changes were made. The images or other third party material in this article are included in the article's Creative Commons license, unless indicated otherwise in a credit line to the material. If material is not included in the article's Creative Commons license and your intended use is not permitted by statutory regulation or exceeds the permitted use, you will need to obtain permission directly from the copyright holder. To view a copy of this license, visit http://creativecommons.org/licenses/by/4.0/.

\section{REFERENCES}

1. Zaichenko, V.M. and Shterenberg, V.Ya., Therm. Eng., 2019, vol. 66, p. 440.

https://doi.org/10.1134/S0040601519060107 
2. Thattai, A.T., Oldenbroek, V., Schoenmakers, L., Woudstra, T., and Aravind, P.V., Appl. Therm. Eng., 2017, vol. 114, p. 170. https://doi.org/10.1016/j.applthermaleng.2016.11.167

3. Chen, L., Yong, S.Z., and Ghoniem, A.F., Progr. Energy Combust. Sci., 2012, vol. 38, p. 156. https://doi.org/10.1016/j.pecs.2011.09.003

4. Kunze, C. and Spliethoff, H., Appl. Energy, 2012, vol. 94, p. 109. https://doi.org/10.1016/j.apenergy.2012.01.013

5. Shi, B., Xu, W., Wu, W., and Kuo, P.-C., Energy Conv. Manag., 2019, vol. 195, p. 290. https://doi.org/10.1016/j.enconman.2019.05.006

6. Cau, G., Tola, V., Ferrara, F., Porcu, A., and Pettinau, A., Fuel, 2018, vol. 214, p. 423. https://doi.org/10.1016/j.fuel.2017.10.023

7. Zhou, C., Shah, K., Song, H., Zanganeh, J., Doroodchi, E., and Moghtaderi, B., Energy Fuels, 2016, vol. 30, no. 3, p. 1741. https://doi.org/10.1021/acs.energyfuels.5b02209

8. Toftegaard, M.B., Brix, J., Jensen, P.A., Glarborg, P., and Jensen, A.D., Progr. Energy Combust. Sci., 2010, vol. 36, p. 581. https://doi.org/10.1016/j.pecs.2010.02.001

9. Zhang, Z., Li, X., Zhang, L., Luo, C., Lu, B., Xu, Y., Liu, J., Chen, A., and Zheng, C., Fuel Proc. Tech., 2019, vol. 184, p. 27. https://doi.org/10.1016/j.fuproc.2018.11.011

10. Kidoguchi, K., Hara, S., Oki, Y., Kajitani, S., Umemoto, S., and Inumaru, J., Proc. ASME 2011 Power Conf., Denver, 2011, vol. 2, p. 485.

11. Ishi, H., Hayashi, T., Tada, H., Yokohama, K., Takashima, R., and Hayashi, J., Appl. Energy, 2019, vols. $233-234$, p. 156.

https://doi.org/10.1016/j.apenergy.2018.10.021

12. Romano, M.C. and Lozza, G.G., Int. J. Greenhouse Gas Control, 2010, vol. 4, p. 469. https://doi.org/10.1016/j.ijggc.2009.11.010

13. Oki, Y., Hara, S., Umemoto, S., Kidoguchi, K., Hamada, H., Kobayashi, M., and Nakao, Y., Energy Proc., 2014, vol. 63, p. 471. https://doi.org/10.1016/j.egypro.2014.11.050

14. Prawobo, B., Aziz, M., Umeki, K., Susanto, H., Yan, M., and Yoshikawa, K., Appl. Energy, 2015, vol. 158, p. 97. https://doi.org/10.1016/j.apenergy.2015.08.060

15. Filippov, P.S., Lazebniy, I.P., and Ryzhkov, A.F., J. Phys. Conf. Ser., 2020, vol. 1565, p. 012096. https://doi.org/10.1088/1742-6596/1565/1/012096

16. Allam, R., Martin, S., Forrest, B., Fetvedt, J., Lu, X., Freed, D., Brown, G.W.Jr., Sasaki, T., Itoh, M., and Manning, J., Energy Proc., 2017, vol. 114, p. 5948. https://doi.org/10.1016/j.egypro.2017.03.1731

17. Weiland, N.T. and White, C.W., Fuel, 2018, vol. 212, p. 613. https://doi.org/10.1016/j.fuel.2017.10.022

18. Botero, C., Field, R.P., Herzog, H.J., and Ghoniem, A.F., Appl. Energy, 2013, vol. 104, p. 408. https://doi.org/10.1016/j.apenergy.2012.11.028

19. Tupsakhare, S., Dooher, J., Modroukas, D., and Castaldi, M., Fuel, 2019, vol. 256, p. 115848.

https://doi.org/10.1016/j.fuel.2019.115848
20. Watanabe, H., Ahn, S., and Tanno, K., Energy, 2017, vol. 118 , p. 181.

https://doi.org/10.1016/j.energy.2016.12.031

21. Jimenez, S. and Gonzalo-Tirado, C., Combust. Flame, 2017, vol. 176, p. 94.

https://doi.org/10.1016/j.combustflame.2016.09.024

22. Yin, C. and Yan, J., Appl. Energy, 2016, vol. 162, p. 742. https://doi.org/10.1016/j.apenergy.2015.10.149

23. Yu, J., Ou, W., and Zhou, K., Fuel, 2014, vol. 124, p. 173. https://doi.org/10.1016/j.fuel.2014.01.101

24. Senneca, O., Scala, F., Chirone, R., and Salatino, P., Fuel, 2017, vol. 201, p. 65. https://doi.org/10.1016/j.fuel.2016.11.034

25. Kriebitzsch, S. and Richter, A., Combust. Flame, 2020, vol. 211 , p. 185. https://doi.org/10.1016/j.combustflame.2019.08.028

26. Maffei, T., Khatami, R., Perucci, S., Faravelli, T., Ranzi, E., and Levendis, Y.A., Combust. Flame, 2013, vol. 160 , p. 2559. https://doi.org/10.1016/j.combustflame.2013.06.002

27. Ralnikov, P.A., Abaimov, N.A., and Ryzhkov, A.F., J. Phys. Conf. Ser., 2018, vol. 1128, p. 012007. https://doi.org/10.1088/1742-6596/1128/1/012007

28. Valero, A. and Uson, S., Energy, 2006, vol. 31, p. 1643. https://doi.org/10.1016/j.energy.2006.01.005

29. Donskoi, I.G., Solid Fuel Chem., 2016, vol. 50, no. 3, p. 191. https://doi.org/10.3103/S0361521916030034

30. Donskoy, I., E3S Web Conf., 2020, vol. 209, p. 03011. https://doi.org/10.1051/e3sconf/202020903011

31. Svishchev, D.A. and Keiko, A.V., Teploenergetika, 2010, no. 6, p. 33 .

32. Kaganovich, B.M., Filippov, S.P., Keiko, A.V., and Shamanskii, V.A., Therm. Eng., 2011, vol. 58, p. 143. https://doi.org/10.1134/S0040601511020054

33. Termodinamicheskie i teplofizicheskie svoistva produktov sgoraniya (Thermodynamic and Thermophysical Properties of Combustion Products), Glushko, V.P., Ed., Moscow: VINITI Akad. Nauk SSSR, 1971, vol. 1.

34. Kaganovich, B.M., Keiko, A.V., Shamanskii, V.A., Shirkalin, I.A., and Zarodnyuk, M.S., Tekhnologiya termodinamicheskogo modelirovaniya. Reduktsiya modelei dvizheniya $k$ modelyam pokoya (Thermodynamic Modeling Technology: Reduction of Motion Models to Rest Models), Novosibirsk: Nauka, 2010.

35. Rossi, C.C.R.S., Berezuk, M.E., Cardozo-Filho, L., and Guirardello, R., Comp. Chem. Eng., 2011, vol. 35, p. 1226. https://doi.org/10.1016/j.compchemeng.2010.07.019

36. Aslanyan, G.S., Ginevskaya, I.Yu., and Shpil'rain, E.E., Khim. Tverd. Topl. (Moscow), 1984, no. 1, p. 90.

37. Vdovenko, V.S., Martynova, M.I., Novitskii, N.V., and Yushina, G.D., Energeticheskoe toplivo SSSR (iskopaemye uglya, goryuchie slantsy, torf, mazut $i$ goryuchii prirodnyi gaz) (Energy Fuel of the USSR: Fossil Coal, Oil Shale, Peat, Fuel Oil, and Combustible Natural Gas), Moscow: Energoatomizdat, 1991.

Translated by V. Makhlyarchuk 